\title{
Factors determining waste generation in Spanish towns and cities
}

Miriam Prades 1,*

Emailal107696@uji.es

Antonio Gallardo 1

Maria Victoria Ibàñez 2

1 Department of Mechanical Engineering and Construction, Universitat Jaume I, Av Sos Baynat s/n, 12071 Castellón, Spain

2 Department of Mathematics, Institute of Mathematics and Applications, Universitat Jaume I, Av Sos Baynat s/n, 12071 Castellón, Spain

\section{Abstract}

This paper analyzes the generation and composition of municipal solid waste in Spanish towns and cities with more than 5000 inhabitants, which altogether account for $87 \%$ of the Spanish population. To do so, the total composition and generation of municipal solid waste fractions were obtained from 135 towns and cities. Homogeneity tests revealed heterogeneity in the proportions of municipal solid waste fractions from one city to another. Statistical analyses identified significant differences in the generation of glass in cities of different sizes and in the generation of all fractions depending on the hydrographic area. Finally, linear regression models and residuals analysis were applied to analyze the effect of different demographic, geographic, and socioeconomic variables on the generation of waste fractions. The conclusions show that more densely populated towns, a hydrographic area, and cities with over 50,000 inhabitants have higher waste generation rates, while certain socioeconomic variables (people/car) decrease that generation. Other socioeconomic variables (foreigners and unemployment) show a positive and null influence on that waste generation, respectively. 


\section{Keywords}

Waste generation

Waste composition

Homogeneity

Linear regression models

\section{Introduction}

Knowledge of the generation and composition of municipal solid waste (MSW) is essential for designing efficient collection systems. If relevant factors are identified and their values are also known, then MSW can be managed more effectively by waste disposal operators. A review of the literature reveals a number of studies that analyze the generation and composition of MSW and their relationship with socioeconomic, demographic, and logistic factors (Abu-Qdais et al. 1997; Bandara et al. 2007; Bach et al. 2004; Beigl et al. 2004; Lebersorger and Beigl 2011; Daskalopoulos et al. 1998; Hockett et al. 1995; Ojeda et al. 2008; Thanh et al. 2010). Correlation analysis, linear regression models, power equations, and mean comparison tests are the tools used most frequently in these studies.

The literature contains a number of different studies that analyze waste composition and waste management models in Spain. For example, in 2011, the Spanish Ministry of Agriculture, Environment and Food published three different studies entitled "Study on waste management models on islands" (Jofra et al. 2011a), "Study on waste management models in isolated rural areas" (Jofra et al. 2011b), and "Opportunities for promoting a recycling society in universities and other educational environments: the case of paper recovery and recycling" (ASPAPEL 2011), but as far as it is known, no attempt has been made to characterize MSW in a more widespread way. The only attempt made to date was by Gallardo et al. (2010; 2012), who in previous studies had examined the collection systems used in Spanish towns with more than 50,000 inhabitants. Those studies obtained but did not analyze the MSW generation and composition data for these towns.

The aim in this work is to complete those studies by analyzing the generation and composition of MSW in Spanish towns and cities 
(hereinafter "towns") with more than 5000 inhabitants in terms of different demographic, geographic, and socioeconomic variables. Hence, the database used by Gallardo et al. (2010; 2012) was completed, adding information about some independent variables for towns with more than 5000 inhabitants that had not been previously collected. This information was obtained directly from official studies published by the different regional Institutes of Statistics.

The bigger the cities, the larger the amount of waste generated in them; therefore, prior to analyzing data about the generation and composition of waste, the data was typified to eliminate the "size effect", working with the variables annual generation rates $\left(\mathrm{AGR}_{i}\right)$, as defined by Gallardo et al. (2010).

Using these variables, the lack of homogeneity in the proportions of waste fractions between cities will be verified and the factors that lead to this inhomogeneity will be highlighted. Whether or not such differences exist will be determined by hypothesis testing, correlation analysis, and linear regression models. Statistical analysis will be carried out using the GNU statistical software R (R Development Core Team 2012).

\section{Area of study and data set}

\section{Area of study}

Spain is located in Western Europe and its capital city is Madrid. It covers the greater part of the Iberian Peninsula but also includes the Balearic Islands, in the western Mediterranean, and the Canary Islands, in the northeastern part of the Atlantic Ocean, as well as the autonomous cities of Ceuta and Melilla in North Africa.

According to the Spanish National Institute of Statistics (INE 2008a), when the data collecting process began in 2008, Spain had a population of $46,745,807$ inhabitants, 5,648,671 (12\% of the total population) of whom were foreign nationals. Its population density (92.63 inhabitants (inh) $/ \mathrm{km}^{2}$ ) was lower than that of most Western European countries, and the population was irregularly distributed throughout its territory. The most densely populated areas were located along the coasts and in the metropolitan area of Madrid, in the center of the country. 
In terms of administrative organization, Spain consists of 17 autonomous communities and two autonomous cities, with 8112 towns altogether (INE 2008a). Figure 1a shows this organization, and Table 1 shows a summary of the distribution of Spanish towns, according to the number of inhabitants living in them. According to this table, there are 1304 towns in Spain with more than 5000 inhabitants, which are home to over $87.11 \%$ of the Spanish population.

Fig. 1

Geographic division of the country into a autonomous communities and $\mathbf{b}$ hydrographic areas

\section{AQ2}


a

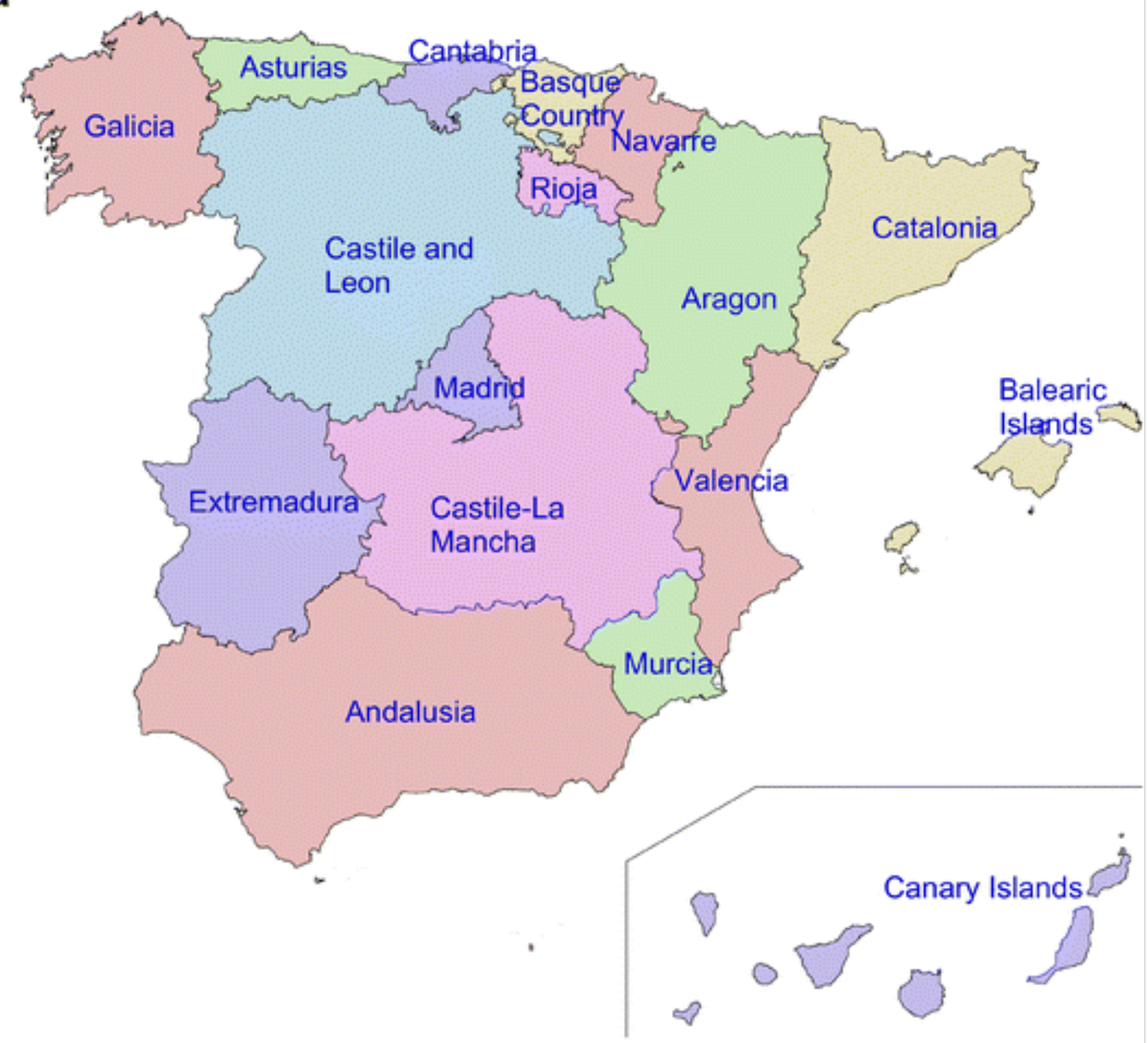

b

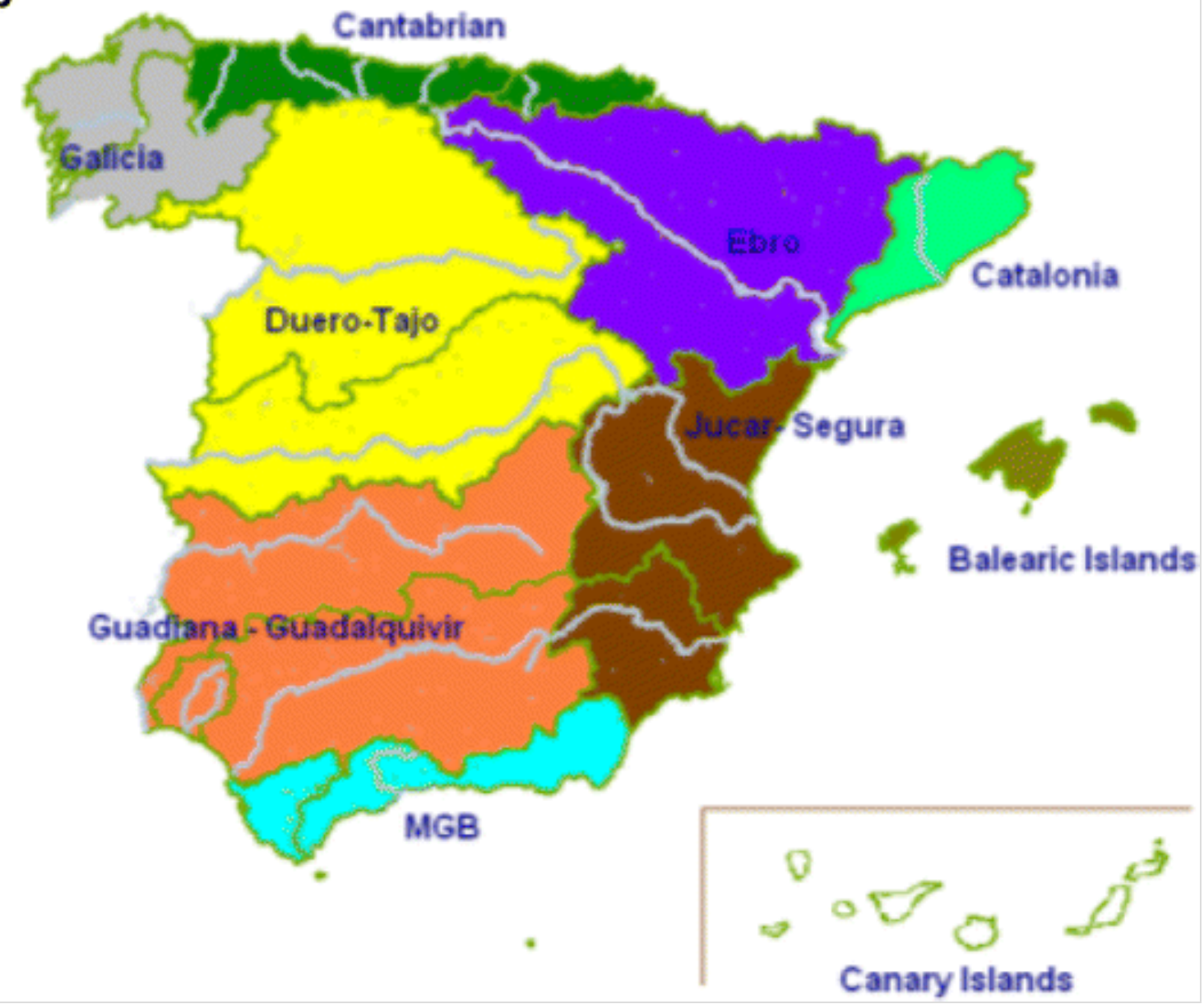


Table 1

Distribution of Spanish towns by population (number of inhabitants)

\begin{tabular}{|l|l|l|}
\hline $\begin{array}{c}\text { Range of } \\
\text { inhabitants }\end{array}$ & $\begin{array}{c}\text { Number of } \\
\text { towns }\end{array}$ & $\begin{array}{c}\text { Total number of inhabitants living in all } \\
\text { of them }(\%)\end{array}$ \\
\hline$<5000$ & 6808 & $6,025,920(12.89 \%)$ \\
\hline $5000-20,000$ & 910 & $8,880,661(19.00 \%)$ \\
\hline $20,000-50,000$ & 249 & $7,312,406(15.64 \%)$ \\
\hline$>50,000$ & 145 & $24,526,820(52.47 \%)$ \\
\hline
\end{tabular}

\section{Data set}

Using data from the previous studies (Gallardo et al. 2010, 2012), complete information about waste generation and composition was obtained for 135 towns distributed by autonomous communities as can be seen in Fig. 2a. This sample size allowed us to do statistical analysis with a $95 \%$ confidence level and an $8 \%$ precision. In both cases, a questionnaire was created and sent by email and ordinary mail to the selected town councils, which were asked to fill it out with their own waste generation and composition data and send it back. In Gallardo et al. (2010), all the councils of Spanish cities with a population of over 50,000 were selected to send the questionnaire, and in Gallardo et al. (2012), the number of municipalities considered to send the survey was proportional to the sample size estimated for the study in each autonomous community.

\section{Fig. 2}

Number of towns for which information is available, distributed a by autonomous communities and range of inhabitants, $\mathbf{b}$ by hydrographic area and range of inhabitants

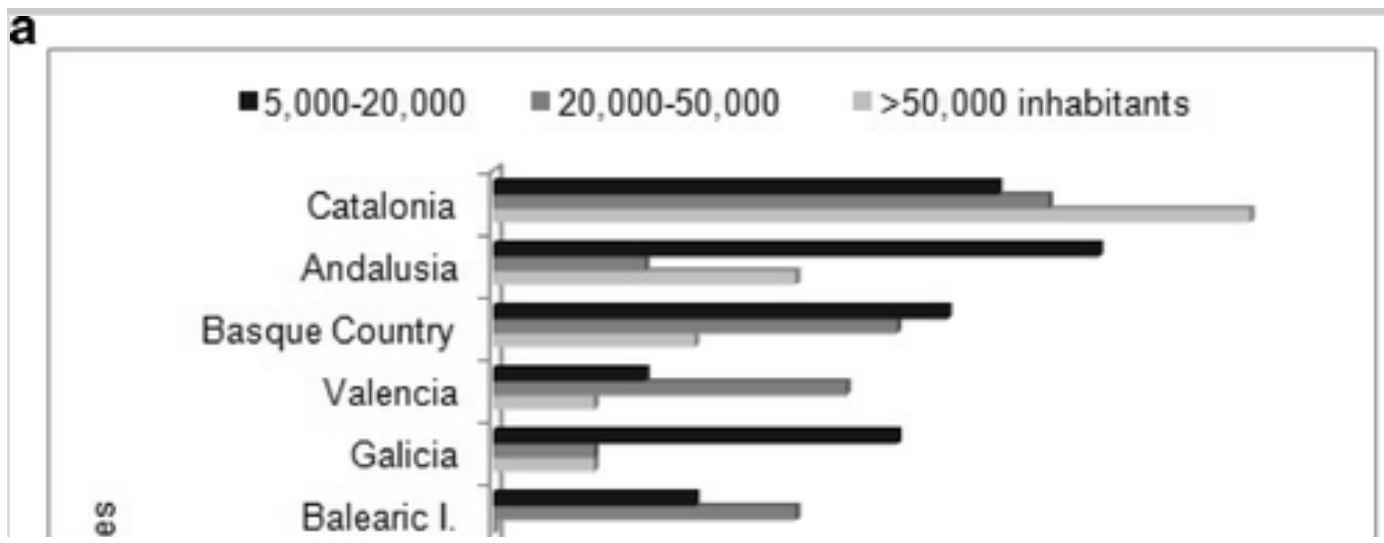




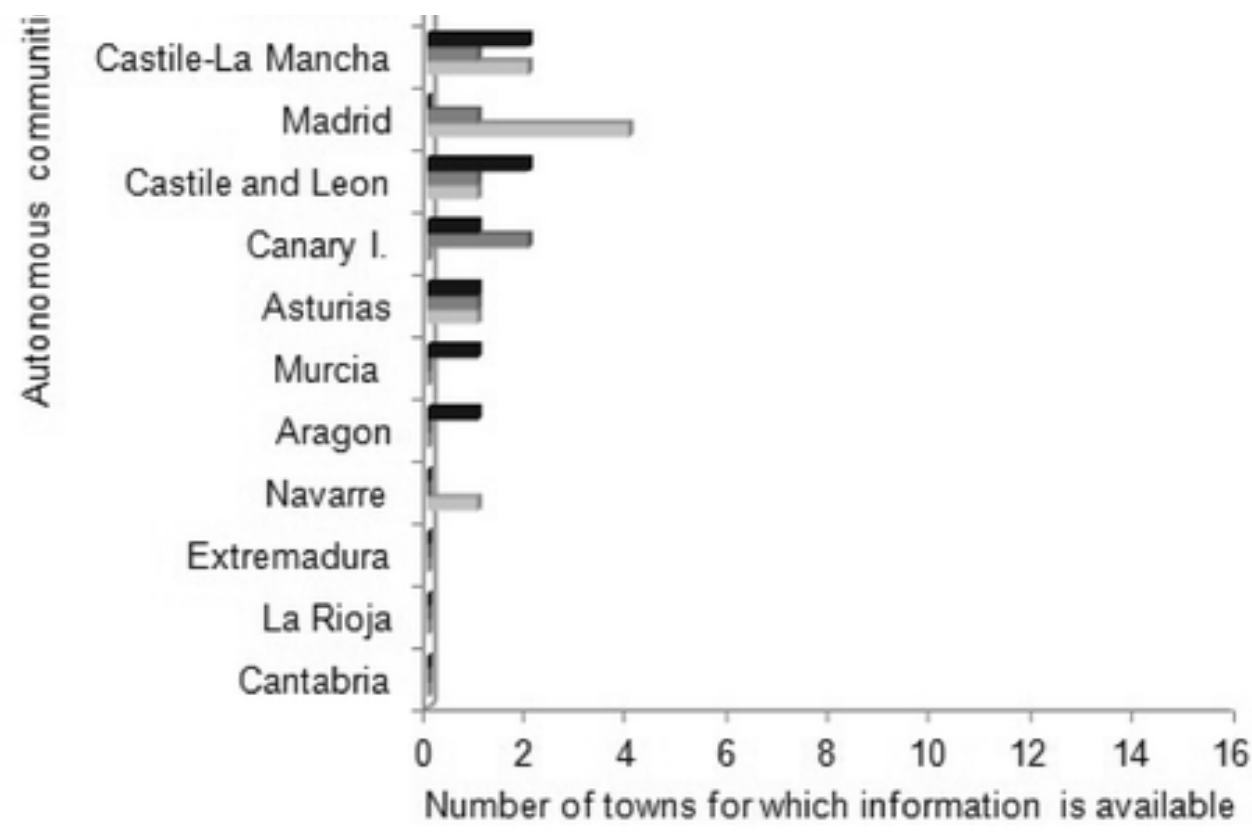

b

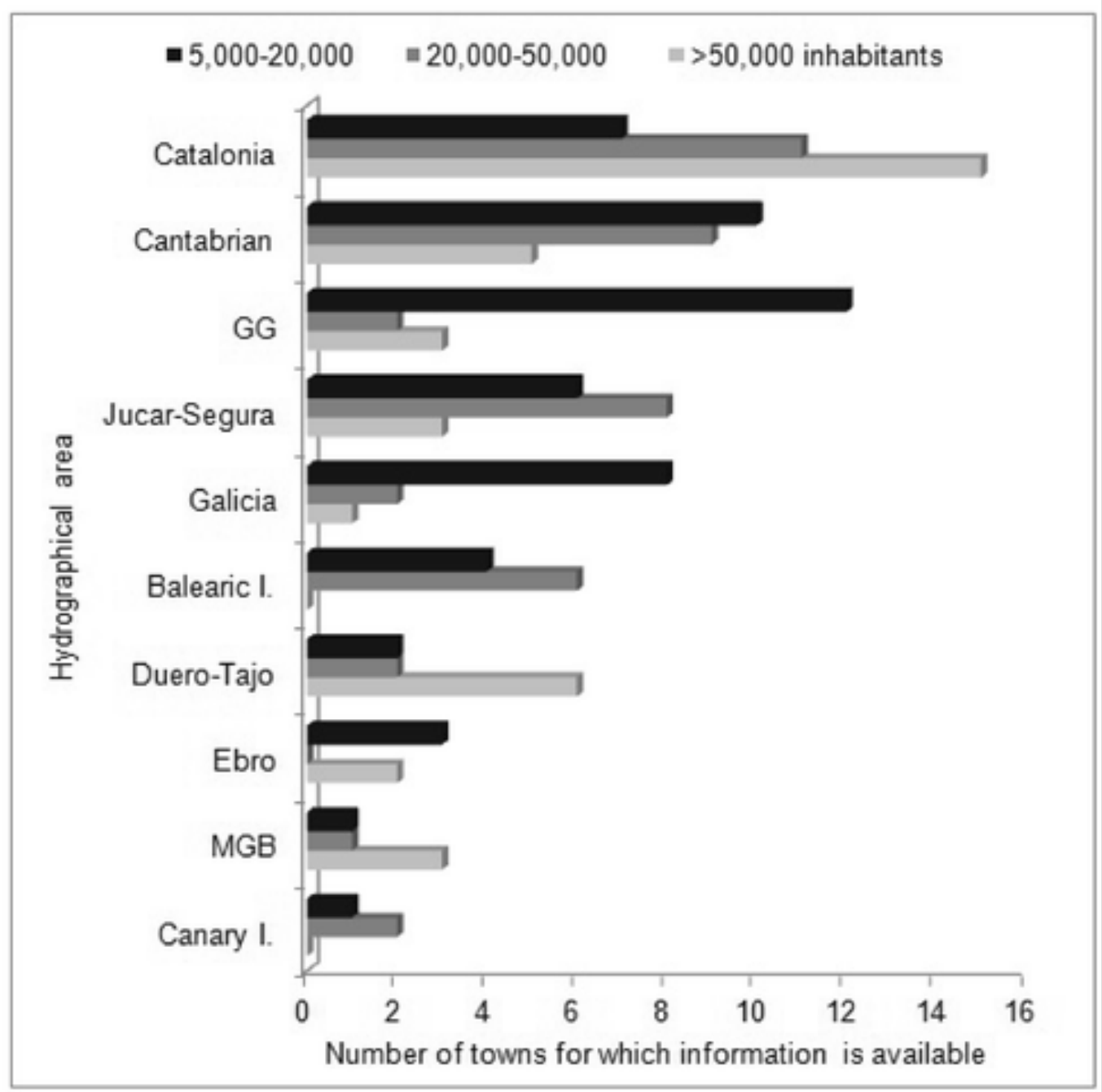

These questionnaires collected information of each town about the following variables:

- Number of inhabitants 
- Surface area

- Collection system implemented

- Year for which data were provided

- Tonnes of each waste fraction collected separately in the year provided: organic waste, paper/cardboard, glass, lightweight packaging, and mixed waste (unsorted waste)

- Composition of each fraction collected separately (organic, papercardboard, glass, plastic, metal, textile, etc.).

Every year, the Spanish Ministry of Environment requires each town council to submit a report on waste generation data, based on European Regulation No. 2150/2002, of 25 th November 2002, on waste statistics. These statistics are then sent to Eurostat (ec.europa.eu/eurostat). Hence, it was easy for municipalities to provide us with these data.

In addition to the data provided by the town councils, information about demographic, geographic, and socioeconomic variables was also collected in order to analyze their influence on the generation of MSW. After an exhaustive search on the websites of the different regional Institutes of Statistics, the information contained in the following variables was collected.

A natural geographic division of the area being studied could have been classification according to autonomous communities. In fact, at first, the towns were chosen so as to ensure that all autonomous communities were represented, the number of towns selected per autonomous community being proportional to the number of towns with between 5000 and 50,000 inhabitants. However, the number of towns that actually answered our questionnaire did not fulfill this proportion and several autonomous communities were not represented in our final data set (Fig. 2a). We therefore looked for other geographic variables.

It is quite difficult to characterize the different towns involved in the analysis geographically. The geographic variables most commonly used are latitude/longitude, height above sea level, and/or different climatic characteristics (temperature, rainfall, etc.). 
Because of its location and the particular characteristics of the territory, the climate in Spain varies widely from one area to another. The south and Mediterranean coasts have what is known as a Mediterranean climate, characterized by mild temperatures and abundant rainfall all year round, except in summer. Inland, the so-called continental climate is harsher and covers most of the peninsula. It is characterized by low temperatures in winter and hot summers, while rainfall is usually irregular and varies depending on the geographic location. Generally speaking, rainfall is heavier in the western communities than in eastern regions. The Cantabrian and Atlantic areas (north and northwest Spain, respectively) have an oceanic climate characterized by abundant rainfall throughout the year, especially in winter, and cool temperatures.

Given the absence of annual meteorological data published for each town and the unavailability of reliable climate data summaries for all the towns in the sample, we decided to characterize the different towns in terms of their hydrographic area. Spain is crossed by several rivers and mountain ranges that strongly condition the winds and most climatic events. Thus, hydrographic area is a categorical variable defined in accordance with the hydrographic areas established by the Spanish Ministry of Agriculture, Environment and Food ( http://sig.magrama.es/saih/ ) (Fig. 1b).

\section{Generation variables}

As stated in the "Introduction,", to typify waste composition between towns of different sizes (obviously, the bigger the cities, the larger the amount of waste generated in them), authors have worked with the variables annual generation rates $\left(\mathrm{AGR}_{i}\right)$, defined by Gallardo et al. (2010) as

$$
A G R_{i}=\frac{\text { Total amount of } i \text { waste generated in a year }}{\text { Inhabitants }}(\mathrm{kg} / \mathrm{inh} / \text { year })
$$

AQ3

where index and subindex $i=\{\mathrm{msw}, \mathrm{o}, \mathrm{p}, \mathrm{g}, \mathrm{pl}\}$ denotes MSW (msw), organic waste (o), paper/cardboard (p), glass $(\mathrm{g})$, and plastic ( $\mathrm{pl})$.

All this information was available from the questionnaires completed by the town councils. 


\section{Demographic variables}

Together with the variables inhabitants (number of inhabitants per town) and density (inhabitants $/ \mathrm{km}^{2}$ ) provided by the questionnaire, two additional demographic variables were taken into account:

- Size, categorical variable with value 1 , for towns having between 5000 and 20,000 inhabitants; 2, for towns having between 20,000 and 50,000 inhabitants; and 3 for towns having greater than 50,000 inhabitants

AQ4

- Foreigners, percentage of immigrants

\section{Geographic variables}

As it was introduced in "Data set-, ", hydrographic area is a categorical variable defined as a geographic variable. In order to obtain greater sample sizes, several adjacent zones had to be joined together, the result being a classification of the towns into ten different areas: (1) Galicia, (2) Cantabrian, (3) Duero-Tajo, (4) Ebro, (5) Catalonia, (6) GuadianaGuadalquivir (GG), (7) Jucar-Segura, (8) Mediterranean basin-Guadalete and Barbate (MGB), (9) Balearic Islands, and (10) Canary Islands. These areas are shown in Fig. 1b. The number of towns that answered the questionnaire, distributed by hydrographic areas and range of inhabitants, is shown in Fig. $2 b$.

\section{Economy}

On the one hand, the mainstay of the Spanish economy is the service sector, which accounts for $69 \%$ of Spain's gross domestic product and is characterized by a $68 \%$ employment rate in the sector (INE 2008b). The most significant contribution to the service sector is that made by tourism. In 2008, Spain received 57.2 million tourists, which ranked it third in the world in terms of number of visitors (UNTWO 2010), behind France (79.2 million) and the USA (57.9 million). The country's top tourist destinations in 2008 were Catalonia (14.3 million tourists), the Balearic Islands (10.1 million), the Canary Islands (9.4 million), Andalusia ( 8 million) and the Valencian Region (5.7 million) (IET 2008). The greatest number of tourists was recorded in the coastal areas of these regions during the summer. 
On the other hand, in the literature has been widely studied the relationship between the generation of waste and the level of purchasing power of the citizens (Abu-Qdais et al. 1997; Bandara et al. 2007; Emery et al. 2003; Thanh et al. 2010).

Taking into account the previous information and the availability of data from public databases, the following economic variables were defined:

- Tourism, number of travellers per province and year

- Unemployment, percentage of people unemployed

- People/car, ratio between population and number of cars per town

These three variables were obtained from the different regional Institutes of Statistics. For each town, the value of the variable corresponding to the year for which they reported their MSW generation data was taken. The data obtained covered the period from 2006 to 2009.

\section{Statistical analysis}

As a first step, a $\chi^{2}$ homogeneity test was performed on the MSW composition data in order to analyze if there was homogeneity on the proportion of each fraction of waste. That analysis let us know if the percentages of waste composition were similar between towns under analysis.

As non-homogeneity was detected between the proportion of each fraction analyzed, the aim is therefore to characterize the generation of MSW as a function of the different variables included in the study. Descriptive statistics, Pearson correlation coefficients, and ANOVA tests are used to perform a first analysis of the relationship between $\mathrm{AGR}_{i}$ and the different variables.

Linear regression methods have been applied to $A G R_{m s w}, A_{0}, A_{0}$, $\mathrm{AGR}_{\mathrm{g}}$, and $\mathrm{AGR}_{\mathrm{pl}}$, to model the amount of waste of each fraction as a function of the aforementioned demographic, geographic, and socioeconomic variables. A stepwise procedure based on the Akaike information criterion (AIC) (Akaike 1974; Burnhan and Anderson 2002) was used to select the best subset of variables to be considered in each 
model in order to avoid collinearity problems.

Having fitted the regression models, residuals were analyzed to identify atypical or excessively influential observations (towns) that could distort the model. The diagnostic measures used to find these observations were residual, leverage, and Cook's distance plots (Draper and Smith 1981). Residual plots detect deviations from the fitted model against the observed. These raw residuals can be used to define other residuals with similar practical interpretations, but with better-known statistical properties, for example the standardized residuals. Leverage allows us to identify extreme or abnormal points in the independent variables. These points are isolated from the rest and usually force the model to pass close to them. Cook's distance measures the effect of each observation when it is removed from the model. It is calculated as the difference between the values of the parameters obtained when the model is estimated with and without the observation considered. Atypical observations (towns) were excluded from the model, and analyses were performed of the significant variables in each model.

\section{Results and discussion}

\section{Descriptive analysis}

Generation and composition of MSW were obtained from the previous studies cited (Gallardo et al. 2010, 2012) and are presented in Table 4. In both cases, it was difficult to obtain data about the composition of the MSW because many towns did not know the overall composition due to the high degree of fractioning of the collection systems and due to the fact that different enterprises are in charge of handling each of the fractions.

It can be seen how the organic waste fraction is the largest, followed by paper/cardboard, plastic, and glass waste. These four waste fractions constitute $80 \%$ of the total waste composition. $\mathrm{AGR}_{i}$ values were obtained from the tonnes of waste fractions collected separately and the number of inhabitants in each town (Table 2). The values show that, as with the composition, organic waste is the main fraction generated per person.

\section{Table 2}

Average composition and generation of MSW in Spanish towns 


\begin{tabular}{|l|l|l|l|}
\multicolumn{1}{|c|}{ Fraction } & \multicolumn{1}{|c|}{ (tonnes/year) } & \multicolumn{1}{c|}{ (kg/inh/year) } \\
\hline Organic & $1,734,607.74$ & $42.14 \%$ & $177.17 \pm 54.03$ \\
\hline Paper/cardboard & $850,326.55$ & $20.66 \%$ & $85.46 \pm 30.90$ \\
\hline Glass & $308,394.07$ & $7.49 \%$ & $37.78 \pm 20.55$ \\
\hline Plastic & $401,344.48$ & $9.75 \%$ & $48.46 \pm 17.34$ \\
\hline Other waste & $821,237.71$ & $19.95 \%$ & $107.87 \pm 42.60$ \\
\hline Total waste & $4,115,910.55$ & $100 \%$ & $456.74 \pm 132.79$ \\
\hline
\end{tabular}

To determine whether there were any differences in the main waste composition fractions (organic, paper/cardboard, glass, and plastic) from one town to another, a $\chi^{2}$ homogeneity test was performed on the proportion of each waste fraction over the total waste per town. The $p$ value obtained from the test was lower than 0.05 , and the null hypothesis of homogeneity (equal proportions of waste fractions) was thus rejected. The following analysis will determine which factors affect that heterogeneity.

To check whether there was a linear relationship between each $\mathrm{AGR}_{i}$ and the different numeric variables included in the study (inhabitants, foreigners, tourism, unemployment, and people/car ratio), correlation coefficients and independence tests were computed. The results are shown in Table 3. No significant linear relationships were detected between the different waste fractions and the number of inhabitants; however, foreigners appears to be linearly related with all the waste fractions, showing a positive correlation in all cases. The study carried out by Lebersorger and Beigl (2011) in a province of Styria (Austria) also found that foreigners was positively correlated with $\mathrm{MSW}(p$ value $<0.05)$. As regards the socioeconomic variables, tourism is the only variable correlated with the generation rate $\mathrm{AGR}_{\mathrm{o}}$, and a significant positive correlation between them was detected.

\section{Table 3}

Pearson correlation coefficients from test between the numeric variables included in the study and $\mathrm{AGR}_{i}$

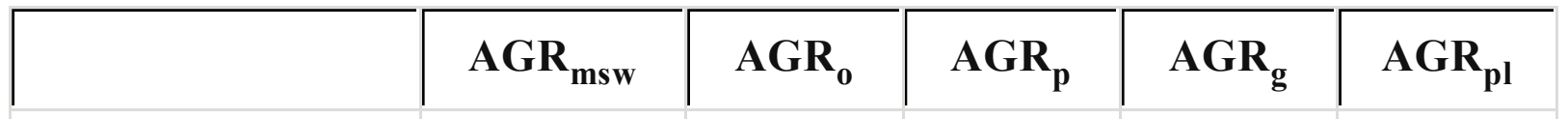




\begin{tabular}{|l|l|l|l|l|l|}
\hline Inhabitants & -0.040 & 0.079 & 0.087 & -0.094 & -0.127 \\
\hline Foreigners & $0.461 *$ & $0.402 *$ & $0.423 *$ & $0.244 *$ & $0.383^{*}$ \\
\hline Tourism & 0.141 & $0.243 *$ & 0.093 & 0.039 & -0.023 \\
\hline Unemployment & 0.008 & -0.030 & -0.085 & -0.042 & 0.081 \\
\hline People/car & -0.159 & -0.122 & -0.081 & -0.159 & -0.156 \\
\hline$* p$ value $<0.05$ & & & & & \\
\hline
\end{tabular}

On the other hand, towns were also classified into three groups according to their population (group 1, 5000-20,000 inhabitants; group 2, 20,00050,000 inhabitants; and group 3 over 50,000 inhabitants). To check whether there were any differences in the variables, $\mathrm{AGR}_{i}$ between these groups' descriptive statistics per fraction and group were computed, jointly with the corresponding ANOVA tests (Table 4). The $p$ values obtained showed that only $\mathrm{AGR}_{g}$ presented differences between the three groups. A subsequent Tukey analysis enables us to conclude that there are significant differences between towns with 5000-20,000 inhabitants and those with over 50,000 inhabitants ( $p$ value $=0.033$ ), while the other comparisons were not significant $(p$ value $=0.745$ for $5000-20,000$ vs $20,000-50,000$ towns; $p$ value $=0.195$ for $20,000-50,000$ vs 50,000 towns). Based on these results, it can be concluded that smaller towns generated more glass per person than larger ones.

\section{Table 4}

Descriptive statistics of the amounts of waste in each size group and $p$ values of the corresponding ANOVA tests

\begin{tabular}{|l|l|l|l|l|}
\hline & $\begin{array}{c}\text { 5000-20,000 inh. } \\
\text { (mean } \pm \text { SD) }\end{array}$ & $\begin{array}{c}\text { 20,000-50,000 inh. } \\
\text { (mean } \pm \text { SD) }\end{array}$ & $\begin{array}{c}\text { >50,000 inh. } \\
\text { (mean } \pm \text { SD) }\end{array}$ & $\begin{array}{c}\text { p } \\
\text { value }\end{array}$ \\
\hline $\mathrm{AGR}_{\mathrm{msw}}$ & $458.02 \pm 129.56$ & $464.31 \pm 166.83$ & $446.37 \pm 89.68$ & 0.831 \\
\hline $\mathrm{AGR}_{\mathrm{o}}$ & $174.07 \pm 52.08$ & $168.79 \pm 64.29$ & $191.06 \pm 41.26$ & 0.156 \\
\hline $\mathrm{AGR}_{\mathrm{p}}$ & $81.77 \pm 32.38$ & $86.77 \pm 37.23$ & $89.29 \pm 18.63$ & 0.497 \\
\hline $\mathrm{AGR}_{\mathrm{g}}$ & $41.08 \pm 29.05$ & $38.77 \pm 13.45$ & $30.95 \pm 6.53$ & 0.040 \\
\hline $\mathrm{AGR}_{\mathrm{pl}}$ & $49.05 \pm 15.84$ & $50.39 \pm 3.19$ & $45.44 \pm 10.23$ & 0.420 \\
\hline
\end{tabular}

The mean values and standard deviation of each generation rate were 
computed for each hydrographic area to determine whether the hydrographic area is a significant factor in explaining the amount of waste generated per person and in each town (Fig. 3). An ANOVA test was performed per generation rate, and in all the cases, $p$ values lower than 0.05 were obtained. Hence, it could be concluded that there are significant differences between hydrographic areas for all the waste fractions considered. As can be seen in Fig. 3, the Balearic Islands are the hydrographic zone with the highest $\mathrm{AGR}_{i}$ values, while Galicia, Cantabrian, and GG show the lowest $\mathrm{AGR}_{i}$ values.

\section{Fig. 3}

Statistics (mean \pm standard deviation) of the amounts of waste in each hydrographic zone 


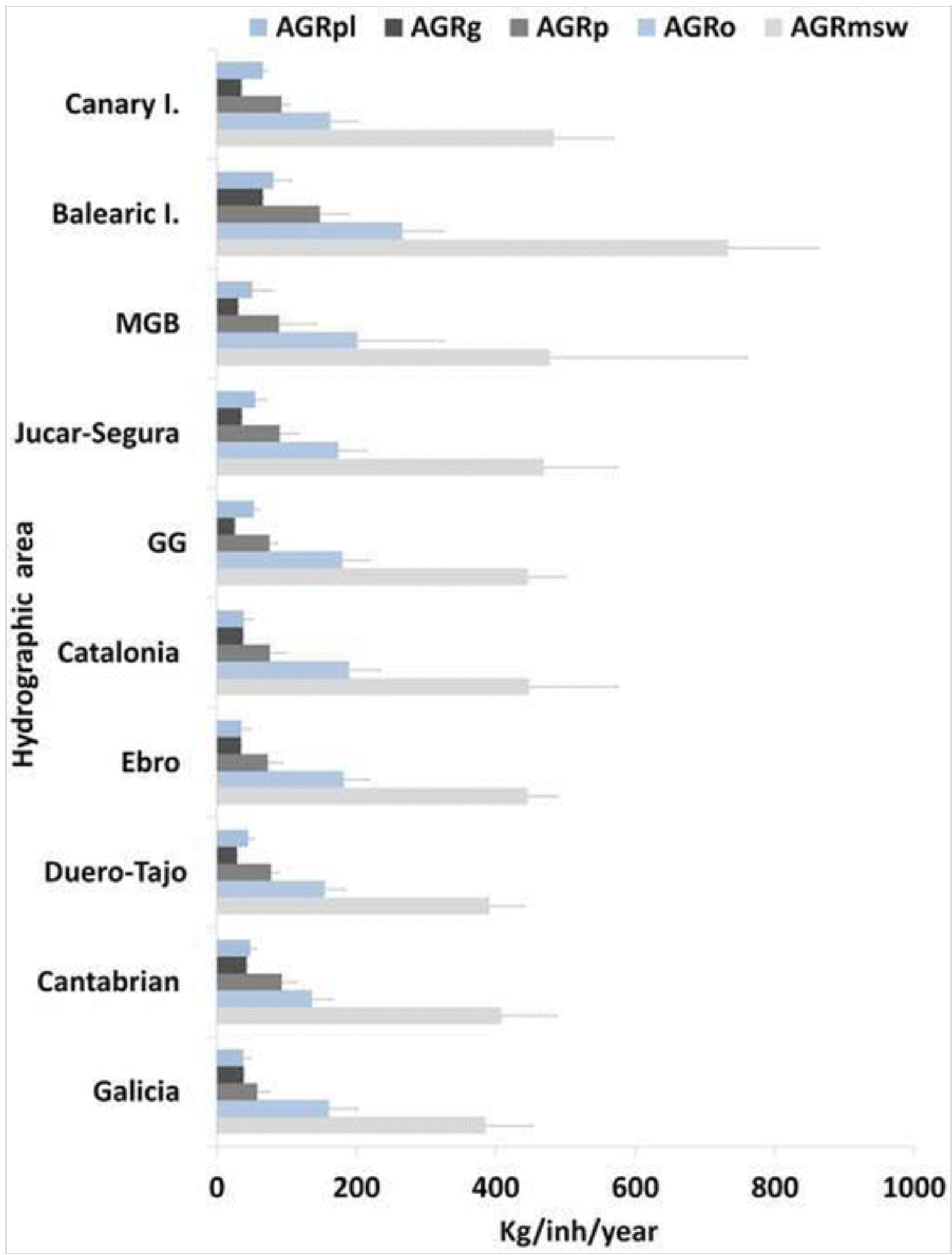

These results confirm the reasoning behind the work of Fortuny et al. (2008), which was aimed at developing a plan for sustainable management of tourism in the Balearic Islands because of the negative impacts of tourism activities on the islands' environment. The huge amount of total MSW generated each year as a result of tourism activities was one of these negative impacts, with the waste generated per person and day in summer increasing by $67 \%$ with respect to winter. 
Tukey analyses of multiple comparisons were implemented in order to determine which pairs of hydrographic zones show significant differences in waste generation. As can be seen in Table 5, the Balearic Islands is the area with the most significant differences in the generation of most kinds of waste; however, differences between other pairs of areas have also been observed.

\section{Table 5}

Results from the Tukey test of multiple comparisons of $\mathrm{AGR}_{i}$ values between hydrogr

\begin{tabular}{|c|c|c|c|c|c|c|c|c|}
\hline & MGB & Catalonia & $\begin{array}{c}\text { Duero- } \\
\text { Tajo }\end{array}$ & Ebro & $\begin{array}{l}\text { Jucar- } \\
\text { Segura }\end{array}$ & GG & Galicia & Bal \\
\hline Cantabrian & $\begin{array}{l}\mathrm{msw} \\
\mathrm{o}\end{array}$ & o & n.s. & n.s. & o & $\mathrm{o}, \mathrm{g}$ & $\mathrm{p}$ & $\begin{array}{l}\mathrm{msi} \\
\mathrm{p}, \mathrm{g}\end{array}$ \\
\hline MGB & - & msw, pl & msw, o & n.s. & o & o & $\begin{array}{l}\mathrm{msw}, \\
\mathrm{o}, \mathrm{p}, \mathrm{pl}\end{array}$ & $0, \mathrm{~g}$ \\
\hline Catalonia & & - & n.s. & n.s. & $\mathrm{pl}$ & $\mathrm{pl}$ & n.s. & $\begin{array}{l}\mathrm{msi} \\
\mathrm{g}, \mathrm{p}\end{array}$ \\
\hline $\begin{array}{l}\text { Duero- } \\
\text { Tajo }\end{array}$ & & & - & n.s. & n.s. & n.s. & n.s. & $\begin{array}{l}\mathrm{ms} \\
\mathrm{p}, \mathrm{g}\end{array}$ \\
\hline Ebro & & & & - & n.s. & n.s. & n.s. & $\begin{array}{l}\mathrm{msi} \\
\mathrm{p}, \mathrm{p}\end{array}$ \\
\hline $\begin{array}{l}\text { Jucar- } \\
\text { Segura }\end{array}$ & & & & & - & n.s. & $\mathrm{p}, \mathrm{pl}$ & $\begin{array}{l}\mathrm{ms} \\
\mathrm{p}, \mathrm{g}\end{array}$ \\
\hline GG & & & & & & - & n.s. & $\begin{array}{l}\mathrm{ms} \\
\mathrm{p}, \mathrm{g}\end{array}$ \\
\hline Galicia & & & & & & & - & $\begin{array}{l}\mathrm{msi} \\
\mathrm{p}, \mathrm{g}\end{array}$ \\
\hline Balearic I. & & & & & & & & - \\
\hline
\end{tabular}

Acronyms in the cells indicate significant differences between the areas from the $\mathrm{r}$ column in msw AGR $\mathrm{msw}_{\mathrm{w}}, \mathrm{o} \mathrm{AGR}_{\mathrm{o}}, \mathrm{p} \mathrm{AGR}_{\mathrm{p}}, \mathrm{g} \mathrm{AGR}_{\mathrm{g}}, \mathrm{pl} \mathrm{AGR}$ pl

n.s. non-significant differences

\section{Regression models}

A linear regression model was built for each response variable, considering the demographic, geographic, and socioeconomic variables defined below as independent variables. In each model, a stepwise selection method based 
on the AIC criterion was implemented to select the best subset of variables.

After fitting the models, diagnostic measures were applied in order to detect any outlier that could be distorting the fits. Figure $4 \mathrm{a}$, c, e shows the diagnostic plots obtained for the regression model of the response variable $=\mathrm{AGR}_{g}$. Figure $4 \mathrm{a}$ shows the raw residuals against the fitted values, Fig. $4 \mathrm{c}$, the square root of standardized residuals against the fitted values, and Fig. 4e, the standardized residuals against the leverage of the observations jointly with the level contours of Cook's distance. As was explained in the "Statistical analysis" section, from these graphs, observations with high residual values, high leverage, and high Cook's distance must be removed from the models. Bearing in mind these criteria in all the models fitted, the towns identified by numbers 52, 107, 113, and 131 were deleted and all the models were fitted again without them. The results of the new models are presented in Tables 6 and 7, and new diagnostic plots for the glass model are shown in Fig. 4b, d, f. As can be seen from the plots obtained from both fits (Fig. 4), the following differences indicate a better fit in the second model:

\section{Fig. 4}

Diagnostic plots of $\mathrm{AGR}_{g}$ regression model. a, $\mathbf{c}, \mathbf{d}$ From the full model with all the observations; $\mathbf{b}, \mathbf{d}, \mathbf{f}$ Aafter removal of atypical observations 

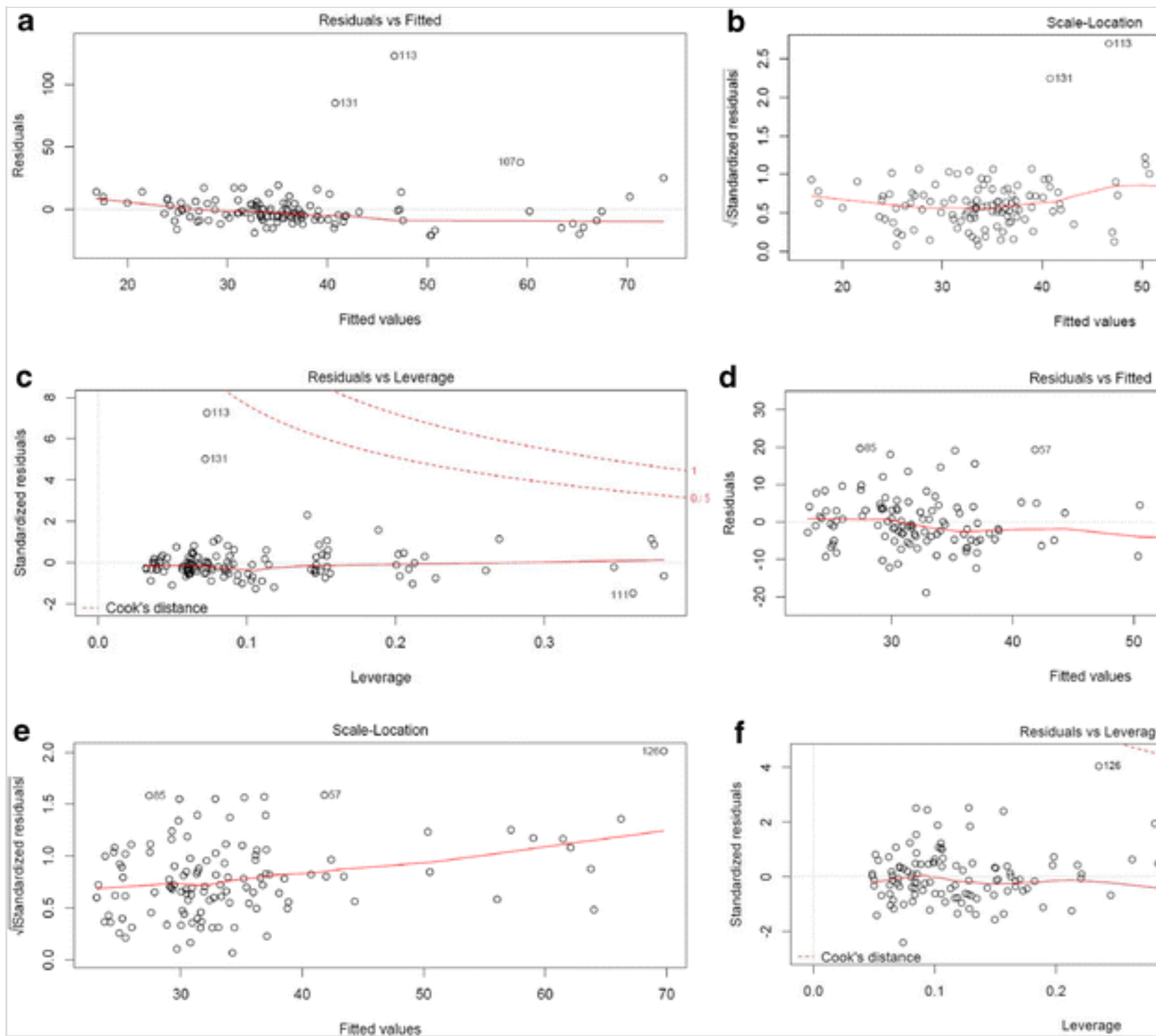

Table 6

Summary of the linear regression fits for $\mathrm{AGR}_{\mathrm{msw}}, \mathrm{AGR}_{\mathrm{o}}$, and $\mathrm{AGR}_{\mathrm{g}}$

\begin{tabular}{|c|c|c|c|c|c|c|c|}
\hline & & $\mathbf{G R}_{\mathrm{msw}}$ & & & $\mathrm{AGR}_{0}$ & & \\
\hline & Estimate & $\begin{array}{l}\text { Std. } \\
\text { error }\end{array}$ & $\underset{\text { value }}{p}$ & Estimate & $\begin{array}{l}\text { Std. } \\
\text { error }\end{array}$ & $\underset{\text { value }}{p}$ & Es \\
\hline (Intercept) & 811,200 & 69,930 & $<0.001$ & 296,500 & 9230 & $<0.001$ & 68 \\
\hline $\begin{array}{l}\text { Size }>50,000 \\
\text { inh }\end{array}$ & - & - & - & 28,300 & 9116 & 0.0025 & -4 \\
\hline $\begin{array}{l}\text { Size } 5000- \\
20,000 \mathrm{inh}\end{array}$ & - & - & - & -2431 & 8790 & 0.7826 & -3 \\
\hline Density & 142.80 & 48.60 & 0.0041 & 36.33 & 23.16 & 0.1198 & 16. \\
\hline $\begin{array}{l}\text { Hydro: Canary } \\
\text { I. }\end{array}$ & $-232,200$ & 54,740 & $<0.001$ & $-87,750$ & 25,420 & 0.0008 & -2 \\
\hline
\end{tabular}




\begin{tabular}{|l|l|l|l|l|l|l|l|}
\hline $\begin{array}{l}\text { Hydro: } \\
\text { Cantabrian }\end{array}$ & $-359,200$ & 48,050 & $<0.001$ & $-116,200$ & 21,540 & $<0.001$ & -2 \\
\hline $\begin{array}{l}\text { Hydro: MGB } \\
\text { AQ5 }\end{array}$ & $-149,900$ & 53,160 & 0.0058 & $-15,090$ & 25,320 & 0.5524 & -2 \\
\hline $\begin{array}{l}\text { Hydro: } \\
\text { Catalonia }\end{array}$ & $-273,600$ & 34,590 & $<0.001$ & $-58,740$ & 15,080 & 0.0002 & -2 \\
\hline $\begin{array}{l}\text { Hydro: Duero- } \\
\text { Tajo }\end{array}$ & $-320,100$ & 40,160 & $<0.001$ & $-99,860$ & 18,460 & $<0.001$ & -2 \\
\hline Hydro: Ebro & $-276,200$ & 53,880 & $<0.001$ & $-65,330$ & 25,400 & 0.0116 & -2 \\
\hline Hydro: Galicia & $-343,700$ & 52,690 & $<0.001$ & $-79,860$ & 24,470 & 0.0015 & -2 \\
\hline Hydro: GG & $-265,300$ & 44,890 & $<0.001$ & $-64,180$ & 20,990 & 0.0029 & -3 \\
\hline $\begin{array}{l}\text { Hydro: Jucar- } \\
\text { Segura }\end{array}$ & $-290,600$ & 40,390 & $<0.001$ & $-84,060$ & 18,640 & $<0.001$ & -2 \\
\hline Tourism & -0.01 & 0.004 & 0.0118 & 0.004 & 0.002 & 0.0421 & -0 \\
\hline Foreigners & 2816 & 1043 & 0.0081 & 1110 & 468.10 & 0.0196 & 26 \\
\hline Unemployment & -6376 & 3566 & 0.0767 & - & - & - & - \\
\hline People/car & $-32,560$ & 20,980 & 0.1237 & $-27,420$ & 10,030 & 0.0074 & -4 \\
\hline R & 0.6596 & & & 0.5503 & & & 0.6 \\
\hline AIC & 1372.43 & & & 1193.01 & & 84 \\
\hline
\end{tabular}

\section{Table 7}

Summary of the linear regression fits for $\mathrm{AGR}_{\mathrm{pl}}$ and $\mathrm{AGR}_{\mathrm{p}}$

\begin{tabular}{|c|c|c|c|c|c|c|}
\hline & \multicolumn{3}{|c|}{$\mathrm{AGR}_{\mathrm{pl}}$} & \multicolumn{3}{|c|}{$\mathbf{A G R}_{p}$} \\
\hline & Estimate & $\begin{array}{l}\text { Std. } \\
\text { error }\end{array}$ & $\underset{\text { value }}{p}$ & Estimate & $\begin{array}{l}\text { Std. } \\
\text { error }\end{array}$ & $\begin{array}{c}p \\
\text { value }\end{array}$ \\
\hline (Intercept) & 72,130 & 6707 & $<0.001$ & 148,600 & 15,000 & $<0.001$ \\
\hline Size $>50,000 \mathrm{inh}$ & - & - & - & 12,880 & 5352 & 0.0180 \\
\hline $\begin{array}{l}\text { Size } 5000- \\
20,000 \mathrm{inh}\end{array}$ & - & - & - & -1369 & 4859 & 0.7787 \\
\hline Density & 18.56 & 7.15 & 0.0108 & 18.61 & 12.75 & 0.1475 \\
\hline Hydro: Canary I. & $-13,760$ & 8277 & 0.0994 & $-45,760$ & 14,220 & 0.0017 \\
\hline $\begin{array}{l}\text { Hydro: } \\
\text { Cantabrian }\end{array}$ & $-33,930$ & 6864 & $<0.001$ & $-63,070$ & 12,360 & $<0.001$ \\
\hline
\end{tabular}




\begin{tabular}{|l|l|l|l|l|l|l|}
\hline Hydro: MGB & $-19,720$ & 7969 & 0.0149 & $-46,280$ & 14,040 & 0.0014 \\
\hline Hydro: Catalonia & $-38,420$ & 4714 & $<0.001$ & $-75,460$ & 8824 & $<0.001$ \\
\hline $\begin{array}{l}\text { Hydro: Duero- } \\
\text { Tajo }\end{array}$ & $-31,020$ & 5765 & $<0.001$ & $-73,330$ & 10,550 & $<0.001$ \\
\hline Hydro: Ebro & $-43,090$ & 7792 & $<0.001$ & $-77,610$ & 13,830 & $<0.001$ \\
\hline Hydro: Galicia & $-36,690$ & 7824 & $<0.001$ & $-81,390$ & 13,930 & $<0.001$ \\
\hline Hydro: GG & $-22,070$ & 6651 & 0.0013 & $-65,350$ & 11,820 & $<0.001$ \\
\hline $\begin{array}{l}\text { Hydro: Jucar- } \\
\text { Segura }\end{array}$ & $-29,540$ & 5971 & $<0.001$ & $-64,980$ & 10,420 & $<0.001$ \\
\hline Tourism & -0.001 & 0.001 & 0.1303 & -0.001 & 0.001 & 0.1670 \\
\hline Foreigners & 504.90 & 149.30 & 0.0010 & 806.90 & 276 & 0.0043 \\
\hline Unemployment & - & - & - & -1804 & 983.40 & 0.0695 \\
\hline People/car & - & - & - & - & - & - \\
\hline$R^{2}$ & 0.6004 & & & 0.6138 & & \\
\hline AIC & 925.73 & & & 1055.2 & & \\
\hline
\end{tabular}

- Panels b, d, and f of Fig. 4 show smoother curves for the residuals (in red) than panels a, c, and e, respectively.

AQ6

- Panels b, d, and f of Fig. 4 show narrower ranges for the residuals than panels a, c, and e, respectively.

Based on the data obtained from the regression models (Tables 6 and 7), the coefficients of determination $\left(R^{2}\right)$ show that the 65.96, 55.03, 61.38, 61.26 , and $60.04 \%$ of the variation of $\mathrm{AGR}_{\mathrm{msw}}, \mathrm{AGR}_{\mathrm{o}}, \mathrm{AGR}_{\mathrm{p}}, \mathrm{AGR}_{\mathrm{g}}$, and $\mathrm{AGR}_{\mathrm{pl}}$, respectively, can be explained by the variables included in the models. Note that the categories for the variables size and hydrographic area that do not appear in the table, i.e., size $<5000$ inhabitants and hydro: Balearic Islands, respectively, are the reference categories in the models.

The effect that each variable has on the generation of MSW is as follows:

- Size $>50,000$ has a positive influence on $\mathrm{AGR}_{\mathrm{o}}$ and $\mathrm{AGR}_{\mathrm{p}}$. This influence means that towns with over 50,000 inhabitants generate 
more organic and paper waste per person than towns with fewer than 5000 inhabitants (reference category). It may be an important predictive factor in the generation of organic and paper waste per inhabitant, since the generation of these types of waste has been associated with levels of urbanization in the literature (Bach et al. 2004; Thanh et al. 2010).

- Density has a positive influence on $\mathrm{AGR}_{\mathrm{msw}}, \mathrm{AGR}_{\mathrm{o}}$, and $\mathrm{AGR}_{\mathrm{pl}}$, showing that cities with higher density generate more waste per inhabitant. These results are in accordance with those found by Thanh et al. (2010) and Lebersorger and Beigl (2011). Both papers concluded that MSW generation rates were positively correlated with population density ( $p$ values $<0.05$ ). Moreover, Thanh et al. (2010) found a positive correlation with waste generation rates of plastic, paper, food, and glass.

- All hydrographical zones generated less MSW, organic, paper, glass, and plastic waste per person than the Balearic Islands' hydrographic zone (reference category). As can be seen in Tables 6 and 7, the Balearic Islands is an area with higher $\mathrm{AGR}_{i}$ values than the rest of the hydrographic areas, which is due to the large amounts of waste generated by tourist activities (Fortuny et al. 2008).

- Tourism has a positive influence on $\mathrm{AGR}_{\mathrm{o}}$ and, contrary to what was expected, has a negative influence on $\mathrm{AGR}_{\mathrm{msw}}$ and $\mathrm{AGR}_{\mathrm{g}}$. Nevertheless, the coefficients estimated showed that these influences are small $(-0.01,0.004$, and -0.001 for MSW, organic, and glass waste, respectively) in comparison with the rest of the regression coefficients.

- The variable foreigners has a positive influence on all the response variables considered, as was expected from the results obtained in the correlation analysis (Table 3 ) which are consistent with the literature (Lebersorger and Beigl 2011).

- People/car has a negative influence on $\mathrm{AGR}_{\mathrm{o}}$. This relationship could be explained by the fact that the higher the people/car ratio, the lower the people's purchasing power will be and, consequently, organic waste generation decreases (people throw less food away). These results eonfirm the findings obtained by is the lower people's 
purehasing power will be, and eonsequently organie waste generation deereases (people throw less food away). That result confirm the findings obtained by Bandara et al. (2007) with a similar socioeconomic variable (people per dwelling), and by Abu-Qdais et al. (1997), Emery et al. (2003), and Thanh et al. (2010) with income level variables. AQ7

\section{Conclusions}

This paper has analyzed waste generation and composition in Spanish towns with over 5000 inhabitants. Complete data about waste generation in Spanish towns were obtained from two previous surveys. Additional information about geographic and socioeconomic variables was obtained from regional Institutes of Statistics. A $\chi^{2}$ homogeneity test established the lack of homogeneity in the main waste composition fractions. Bivariate analyses were performed between waste generation and demographic, geographic, and socioeconomic variables. An ANOVA test detected significant differences in the generation of glass between groups of towns according to their size (5000-20,000 inhabitants, 20,000-50,000 inhabitants, and over 50,000 inhabitants). Significant differences were found in waste generation from one hydrographic area to another, and a positive correlation was found between waste generation and the percentage of foreigners. Regression models showed that higher-density towns, towns with over 50,000 inhabitants, towns in the Balearic Islands, and towns with a higher rate of foreigners generate more waste than other towns. Nevertheless, the socioeconomic variable people/car has a negative influence on the generation of organic waste.

Although the literature contains publications on this issue in different countries and regions, the literature on MSW generation and composition in Spain is scarce. Knowledge of the factors that can influence waste generation plays an important role in helping managers in their decisionmaking when designing a waste collection system. The variables and the complete statistical methodology carried out in this paper could help other researchers to reproduce them in their countries.

\section{Acknowledgments}


Firstly, we would like to thank all the town councils that so willingly provided us with their data, since without their collaboration it would not have been possible to conduct this study. Secondly, we are grateful to the Spanish Ministry of the Environment and Rural and Marine Affairs for funding the projects Study of the different models of selective collection of $R S U$ implemented in Spain, Determination of evaluation indicators (Estudio de los diferentes modelos de recogida selectiva de RSU implantados en España, Determinación de indicadores de evaluación) (Number 279/2006/2-2.1) and Study of the different models of selective collection of RSU implemented in Spain, Determination of evaluation indicators, Second phase (Estudio de los diferentes modelos de recogida selectiva de RSU implantados en España, Determinación de indicadores de evaluación. Fase segunda) (Number AA228/2007/1-02.1), and Designing a model for the management of the municipal waste collection in Spanish populations (Diseño de un modelo para la gestión de la recogida de residuos urbanos en las poblaciones españolas) and to the University Jaume I, by the UJI project P11A2011-11.

AQ8

\section{References}

Abu-Qdais, H., Hamoda, M., \& Newham, J. (1997). Analysis of residential solid waste at generation sites. Waste Management \& Research, 15, 395-406.

Akaike, H. (1974). A new look at the statistical model identification. IEE Transactions on Automatic Control, 19, 716-723.

ASPAPEL (2011). Opportunities for promoting recycling society in environments of universities and other teaching spaces: the case of the recovery and recycling of paper.

http://www.magrama.gob.es/imagenes/es/Informe universidades MMARM-ASPAPEL tcm7-189308.pdf. Accessed May 2013.

Bach, H., Mild, A., Natter, M., \& Weber, A. (2004). Combining sociodemographic and logistic factors to explain the generation and collection of waste paper. Resources, Conservation and Recycling, 41, $65-73$. 
Bandara, N., Hettiaratchi, J., Wirasinghe, S., \& Pilapiiya, S. (2007). Relation of waste generation and composition to socio-economic factors: a case study. Environmental Monitoring and Assessment, 135, $31-39$.

Beigl, P., Wassermann, G., Schneider, F., Salhofer, S. (2004). Forecasting municipal solid waste generation in major European cities. http://www.iemss.org/iemss2004/pdf/regional/beigfore.pdf . Accessed March 2008.

Burnhan, K., Anderson, D. (2002). Model selection and multimodel inference: a practical information-theoretic approach. 2nd ed., SpringerVerlag.

Daskalopoulos, E., Badr, O., \& Probert, S. (1998). Municipal solid waste: a prediction methodology for the generation rate and composition in the European Union countries and the United States of America. Resources, Conservation and Recycling, 24, 155-166.

Draper, N., \& Smith, H. (1981). Applied regression analysis (2nd ed.). New York: John Wiley and Sons, Inc.

Emery, A., Griffiths, A., \& Williams, K. (2003). In a depth study of the effects of socio-economic conditions on household waste recycling practices. Waste Management \& Research, 21, 180-190.

Fortuny, M., Soler, R., Cánovas, C., \& Sánchez, A. (2008). Technical approach for a sustainable tourism development. Case study in the Balearic Islands. Journal of Cleaner Production, 16, 860-869.

Gallardo, A., Bovea, M., Colomer, F., Prades, M., \& Carlos, M. (2010). Comparison of different collection systems for sorted household waste in Spain. Waste Management, 30, 379-406.

Gallardo, A., Bovea, M., Colomer, F., \& Prades, M. (2012). Analysis of collection systems for sorted household waste in Spain. Waste Management, 32, 1623-1633.

Hockett, D., Lober, D., \& Pilgrim, K. (1995). Determinants of per 
capita municipal solid waste generation in the southeastern United States. Journal of Environmental Management, 45, 205-217.

IET (2008). Balance del turismo. Resultados de la actividad turstica en España. Technical Report. Instituto de Estudios Turísticos.

INE (2008a). Demografía y población. Cifras de población y censos demográficos. http://www.ine.es . Accessed April 2011.

INE (2008b). Sociedad. Análisis sociales. http://www.ine.es . Accessed April 2011.

Jofra, M., Font, D., Mestre, M. (2011a). Study on waste management models in islands http://www.magrama.gob.es/imagenes/es/Estudio sobre modelos de gestión de residuos en entornos insulares tcm7183310.pdf. Accessed May 2013.

Jofra, M., Citlalic, A., Calaf, M. (2011b). Study on waste management models in isolated rural areas.

http://www.magrama.gob.es/imagenes/es/Gestion de residuos en entornos rurales vfinal revisada 150411 tcm7-183008.pdf. Accessed May 2013.

Lebersorger, S., \& Beigl, P. (2011). Municipal solid waste generation in municipalities: quantifying impacts of household structure, commercial waste and domestic fuel. Waste Management, 31, 1907-1915.

Ojeda, S., Lozano-Olvera, G., Adalberto, R., \& Armijo, C. (2008). Mathematical modeling to predict residential solid waste generation. Waste Management, 28, S7-S13.

R Development Core Team (2012). R: a language and environment for statistical computing. R Foundation for Statistical Computing. Vienna, Austria. URL: http://www.R-project.org . ISBN 3-900051-07-0. Accessed March 2012.

Thanh, N., Matsui, Y., \& Fujiwara, T. (2010). Household solid waste generation and characteristic in Mekong Delta city, Vietnam. Journal of Environmental Management, 91, 2307-2321. 
UNTWO. (2010). World's top tourism destinations. World Top

Barometer, 8, 9-10. 